\title{
Associations of genetic variants in ADAM33 and TGF-ß1 genes with childhood asthma risk
}

\author{
HONGBIN LI ${ }^{1}$, YUCHUN LI ${ }^{1}$, MINGWU ZHANG ${ }^{2}$, GUANGCHUI XU ${ }^{1}$, \\ XIANJUN FENG ${ }^{3}$, JINGZHUAN XI ${ }^{1}$ and BING ZHAO ${ }^{4}$ \\ ${ }^{1}$ School of Public Health, Xinxiang Medical University, Xinxiang, Henan 453003; ${ }^{2}$ Zhejiang Provincial Center \\ for Disease Control and Prevention, Hangzhou, Zhejiang 310051; ${ }^{3}$ Department of Respiratory Medicine, \\ The First Affiliated Hospital of Xinxiang Medical University, Xinxiang, Henan 453003; ${ }^{4}$ Department of Respiration, \\ Zhumadian Munipical Central Hospital, Zhumadian, Henan 463000, P.R. China
}

Received December 24, 2013; Accepted April 22, 2014

DOI: $10.3892 /$ br. 2014.280

\begin{abstract}
The aim of the present study was to explore the associations of genetic variants in the ADAM33 and TGF- $\beta 1$ genes with the risk of childhood asthma. A total of 299 asthmatic children and 311 healthy controls were recruited in the hospital-based case-control study. The asthmatic subjects were further divided into mild and severe groups according to disease severity. Single-nucleotide polymorphisms (SNP) at ADAM33 V4, T2, S2 and T1, and TGF- $\beta 1$ C-509T and T869C were selected and detected with PCR-RFLP. The associations of the SNPs with asthma risk and severity were analyzed. The associations between the haplotypes of ADAM33 and TGF- $\beta 1$ were also evaluated. Compared with the GG genotype, the GC and CC genotypes at V4 were associated with an increased asthma risk in children and the ORs were 2.92 and 10.56, respectively. Compared with the CC genotype, the CT/TT genotype at C-509T was associated with an increased asthma risk and the OR was 2.26. Subsequent to stratification by asthma severity, compared with the V4 GG genotype, it was found that the $\mathrm{CG}$ and $\mathrm{CC}$ genotypes were associated with a mild asthma risk and the ORs were 3.00 and 5.99, respectively. The SNP at C-509T (CT/TT vs. CC) was associated with mild asthma $(\mathrm{OR}=2.34)$, whereas a marginally significant association was detected between the SNP (CT/ TT vs. CC) and severe asthma risk (OR=2.19). The haplotype analysis revealed that, compared with the GGCA haplotype
\end{abstract}

Correspondence to: Professor Jingzhuan Xi, School of Public Health, Xinxiang Medical University, No. 601 Jinsui Road, Xinxiang, Henan 453003, P.R. China

E-mail: xjz@xxmu.edu.cn

Bing Zhao, Department of Respiration, Zhumadian Munipical Central Hospital, No. 747 Zhonghua Road, Zhumadian, Henan 463000, P.R. China

E-mail: 790825600@qq.com

Key words: TGF- $\beta 1$, ADAM33, single-nucleotide polymorphism, asthma, risk, Chinese children, haplotype of ADAM33, significant associations of the haplotypes of CGCG, CGGA, GACA, GACG and GAGA with asthma risk were observed, and the ORs were 31.12, 12.24, 4.73, 30.85 and 4.83, respectively. No significant association was detected between the TGF- $\beta 1$ haplotypes and asthma risk. The genetic variants at V4 and C-509T had the potential to modify the childhood asthma risk and the associations showed no notable difference with the disease severity. Thus, ADAM33 haplotypes provided more useful information in the prediction of asthma risk.

\section{Introduction}

Asthma is the most frequent chronic respiratory disease during childhood and asthma exacerbation is a main cause of child morbidity and hospitalization (1). Epithelial damage, smooth muscle hyperplasia and increased matrix deposition are significant characteristics of the asthmatic airways that are considered to contribute to airway remodeling and responsiveness (2). Asthma is a complex disorder with variable clinical and physiological presentations, in which genetics and the environment interact to modify the susceptibility to and the severity of the disease (3-5). Accumulating evidence has shown that genetic factors are involved in the initiation and development of asthma, including a disintegrin and metalloproteinase domain 33 (ADAM33). ADAM33 was confirmed to be associated with bronchial hyperresponsiveness and asthma (6). Findings of previous studies have shown that several SNPs in the ADAM33 gene are significantly associated with the asthma risk in various populations, including the Han Chinese (7-9). Studies carried out in certain countries, including America, Germany and Japan, showed that genetic variants in ADAM33 were associated with a childhood asthma risk (10-12).

Transforming growth factor- $\beta 1$ (TGF- $\beta 1$ ) plays key roles in certain pathological and physiological processes, including asthma. TGF- $\beta 1$ is located at chromosome 19q13.1-13.2 and has been cloned and sequenced $(13,14)$. TGF- $\beta 1$ is a multifunctional cytokine and functions by binding to its type I and II receptors to exert a number of biological effects, including anti-inflammatory activities $(15,16)$. Genetic variants in the TGF- $\beta 1$ gene have been confirmed and significant associations 
Table I. Primer sequences and enzymes used for PCR-RFLP analysis.

\begin{tabular}{llcc}
\hline rs number & \multicolumn{1}{c}{ Primer sequences } & PCR products (bp) & Enzyme \\
\hline rs2787094 & 5'-AGGTGTAGCACTGGGATTGG-3' & 247 & PstI \\
rs2280090 & 5'-GTCCTGGGAGTCTGGTGTGT-3 & 132 & HinfI \\
& 5'-ACTCAAGGTGACTGGGTGCTGC-3' & & KasI \\
rs528557 & 5'-GCCCCACAGCCACTGGAGAG-3' & 289 & NcoI \\
rs2280091 & 5'-GGAACCGCAGGAGTAGGCTC-3' & & Eco81I \\
rs1800469 & 5'-TGTGCAGGCTGAAAGTATGC-3' & 270 & PvuII \\
rs1982073 & 5'-TGCTAGGGGACTCAAGGTGACTG-3' & 406 & \\
& 5'-CCGCTTCTGTCCTTTCTAGG-3' & 248 & \\
\hline
\end{tabular}

PCR-RFLP, polymerase chain reaction restriction fragment length polymorphism; bp, base pair.

between specific SNPs and asthmatic phenotype have been reported by previously conducted studies (17-19).

ADAM33 and TGF- $\beta 1$ have been previously shown to be involved in the initiation and development of asthma (20-23). However, the associations between the genetic variants in the genes involved in child asthma risk in a Chinese population remain to be verified, particularly as the interactions between ADAM33 and TGF- $\beta 1$ with a multi-SNP combination on asthma risk are currently unclear. In the present study, the SNPs at ADAM33 V4, T2, S2 and T1, and TGF- $\beta 1$ C509T and T869C were detected and their associations with child asthma risk were evaluated in a Chinese population.

\section{Materials and methods}

Study subjects. A total of 299 asthmatic children were recruited from the Department of Respiratory Medicine and Pediatric Inpatient and Outpatient at The First Affiliated Hospital of Xinxiang Medical University (Xinxiang, Henan, China) between March 2010 and October 2012. The participants included 166 males and 133 females aged 3.1-14.6 years who were in line with the global initiative for asthma (24). The asthmatic patients were further divided into the mild and severe groups, comprising 171 and 128 patients, respectively. In total, 311 patients with no personal or family history of asthma and allergies and did not suffer from non-respiratory diseases (including eczema, allergic rhinitis and atopic dermatitis) during the same period were enrolled into the control group. A structured questionnaire was adopted and information, including social-demographic characteristics and diagnosis of the disease, was collected. All the subjects were confirmed to be Chinese Han children from the North of Henan. Written informed consent was provided by each parent or legal guardian of the participant. Each participant provided a 2-3 $\mathrm{ml}$ venous blood sample following an interview, which was subsequently treated with EDTA $\mathrm{Na}_{2}$ and stored at $-80^{\circ} \mathrm{C}$.
Genomic DNA isolation and genotype detection. The study design was approved by the Ethics Committee of the Xinxiang Medical University. Genomic DNA in lymphocytes was isolated with the DNA Extraction kits (Sangon Biotech Co., Ltd., Songjiang, Shanghai, China) according to the manufacturer's instructions. The DNA samples were diluted to $100 \mathrm{ng} /$ $\mu \mathrm{l}$ and stored at $-80^{\circ} \mathrm{C}$.

Mutation rates of rs2787094, rs2280090, rs528557, rs2280091, rs1800469 and rs1982073 and the gene sequences covering the SNPs were obtained from an online database (http://www.ncbi.nlm.nih.gov/SNP/). The primers of six SNPs were designed with Primer Premier software (Premier Biosoft International, Palo Alto, CA, USA), and synthesized by Sangon Biotech Co., Ltd. The primer sequences for the genotype detection of each SNP, and the restriction enzymes used in the study are shown in Table I. PCR was performed in a $25 \mu 1$ volume, containing $60 \mathrm{ng}$ DNA, $2.5 \mu \mathrm{l} 10 \mathrm{X}$ buffer, $1.8 \mu \mathrm{l} \mathrm{MgCl}_{2}$ ( $25 \mathrm{mmol} / \mathrm{l}$ ), $2.5 \mu \mathrm{l} \mathrm{dNTPs}, 1 \mu \mathrm{l}$ of each primer, 0.7 units Taq polymerase and double-distilled water. PCR was carried out under the following conditions: $95^{\circ} \mathrm{C}$ for $5 \mathrm{~min}$, followed by $95^{\circ} \mathrm{C}$ for $30 \mathrm{sec}, 56^{\circ} \mathrm{C}$ for $30 \mathrm{sec}, 72^{\circ} \mathrm{C}$ for $40 \mathrm{sec}$ for 35 cycles, and $72^{\circ} \mathrm{C}$ for $10 \mathrm{~min}$. The PCR products were subsequently stored at $4^{\circ} \mathrm{C}$. The enzyme digestion that followed utilized $10 \mu \mathrm{l}$ of the PCR product and the reactions were performed in a final volume of $30 \mu \mathrm{l}$ containing $>3$ units of each enzyme and incubated for $>6 \mathrm{~h}$ at temperatures provided by the manufacturers. The digested PCR products were then separated in $2.0 \%$ agarose gels containing $1 \mu \mathrm{g} / \mathrm{ml}$ ethidium bromide and analyzed by the GelDoc-It 310 Imaging System (Ultra-Violet Products Ltd., Upland, CA, USA).

Statistical analysis. Data were presented as means \pm SD. The means of multiple groups were compared with one-way analysis of variance, while those between two groups were compared with an independent t-test. The genotype-specific odds ratios (OR), 95\% confidence intervals (95\% CIs) and $\mathrm{P}$-values were computed with unconditional logistic regres- 
Table II. Social-demographic characteristics of the subjects.

\begin{tabular}{|c|c|c|c|c|c|}
\hline \multirow[b]{2}{*}{ Variables } & \multirow{2}{*}{$\begin{array}{c}\text { Controls } \\
(\mathrm{N} 1=311), \mathrm{n}(\%)\end{array}$} & \multicolumn{2}{|c|}{ Cases $(\mathrm{N} 2=299), \mathrm{n}(\%)$} & \multirow[b]{2}{*}{$\mathrm{F} / \chi^{2}$} & \multirow[b]{2}{*}{ P-value } \\
\hline & & Mild asthma & Severe asthma & & \\
\hline Age $($ mean $\pm \mathrm{SD})$ & $10.4 \pm 2.9$ & $10.6 \pm 2.7$ & $10.5 \pm 2.6$ & 0.158 & 0.854 \\
\hline \multicolumn{6}{|l|}{ Gender } \\
\hline Male & $175(56.3)$ & $95(55.6)$ & $71(55.5)$ & & \\
\hline Female & $136(43.7)$ & $76(44.4)$ & $57(44.5)$ & 0.035 & 0.852 \\
\hline FEV1 (\% of predicted) & $102.4 \pm 9.1$ & $88.4 \pm 12.1$ & $67.2 \pm 15.3$ & 3.797 & 0.043 \\
\hline
\end{tabular}

SD, standard deviation; FEV1, forced expiratory volume in one second.

Table III. Associations between genetic variants and asthma risk.

\begin{tabular}{|c|c|c|c|c|}
\hline Genotypes & $\begin{array}{c}\text { Controls }(\mathrm{N}=311), \\
\mathrm{n}(\%)\end{array}$ & $\begin{array}{c}\text { Cases }(\mathrm{N}=299) \\
\mathrm{n}(\%)\end{array}$ & $\begin{array}{l}\text { Adjusted ORs } \\
\text { (95\% CIs) }\end{array}$ & $\begin{array}{c}\text { Adjusted } \\
\text { P-value }\end{array}$ \\
\hline \multicolumn{5}{|c|}{ ADAM33 (V4) } \\
\hline GG & $214(68.8)$ & $130(43.5)$ & 1.00 & \\
\hline $\mathrm{GC}$ & $84(27.0)$ & $136(45.5)$ & $2.92(1.46-5.85)^{\mathrm{a}}$ & $0.003^{\mathrm{a}}$ \\
\hline $\mathrm{CC}$ & $13(4.2)$ & $33(11.0)$ & $10.56(2.17-51.67)^{\mathrm{a}}$ & $0.004^{\mathrm{a}}$ \\
\hline \multicolumn{5}{|c|}{ ADAM33 (T2) } \\
\hline GG & $259(83.3)$ & $185(61.9)$ & 1.00 & \\
\hline GA & $48(15.4)$ & $92(30.8)$ & $1.82(0.86-3.85)$ & 0.116 \\
\hline AA & $4(1.3)$ & $22(7.3)$ & $3.49(0.64-19.0)$ & 0.147 \\
\hline \multicolumn{5}{|c|}{ ADAM33 (S2) } \\
\hline $\mathrm{CC}$ & $158(50.8)$ & $131(43.8)$ & 1.00 & \\
\hline $\mathrm{CG}$ & $114(36.7)$ & $133(44.5)$ & $1.34(0.71-2.55)$ & 0.367 \\
\hline GG & $39(12.5)$ & $35(11.7)$ & & \\
\hline \multicolumn{5}{|c|}{ ADAM33 (T1) } \\
\hline AA & $229(73.6)$ & $144(48.2)$ & 1.00 & \\
\hline $\mathrm{AG}$ & $71(22.9)$ & $123(41.1)$ & $1.61(0.78-3.33)$ & 0.197 \\
\hline GG & $11(3.5)$ & $32(10.7)$ & $1.31(0.31-5.51)$ & 0.713 \\
\hline \multicolumn{5}{|c|}{ TGF- $\beta 1$ (T869C) } \\
\hline $\mathrm{TT}$ & $110(35.4)$ & $117(39.1)$ & 1.00 & \\
\hline $\mathrm{CT}$ & $147(47.3)$ & $144(48.2)$ & $0.82(0.42-1.59)$ & 0.552 \\
\hline $\mathrm{CC}$ & $54(17.3)$ & $38(12.7)$ & $2.29(0.77-6.82)$ & 0.139 \\
\hline \multicolumn{5}{|c|}{ TGF- $\beta 1(C-509 T)$} \\
\hline $\mathrm{CC}$ & $136(43.7)$ & $79(26.4)$ & 1.00 & \\
\hline $\mathrm{CT}$ & $134(43.1)$ & $160(53.5)$ & $2.61(1.32-5.19)^{\mathrm{a}}$ & $0.006^{\mathrm{a}}$ \\
\hline $\mathrm{TT}$ & $41(13.2)$ & $60(20.1)$ & $1.41(0.52-3.83)$ & 0.498 \\
\hline $\mathrm{CT} / \mathrm{TT}$ & $175(56.3)$ & $220(73.6)$ & $2.26(1.19-4.30)^{\mathrm{a}}$ & $0.013^{\mathrm{a}}$ \\
\hline
\end{tabular}

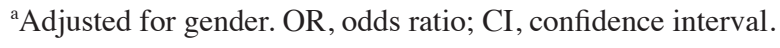

sion, and gender (as dichotomous variables) was included in the regression as a covariate. The statistical analyses were performed with SPSS version 13.0 (SPSS, Inc., Chicago, IL, USA). In addition, the associations of the ADAM33 and TGF- $\beta 1$ haplotypes with the risk of asthma were assessed using R software version 2.15 (Developed by R Core Team, Vienna, Austria and improved by MathSoft company, Cambridge, MA, USA), and the ORs and 95\% CIs were also estimated. $\mathrm{P}<0.05$ was considered to indicate a statistically significant difference and all P-values are two-sided. 
Table IV. Associations between genetic variants with mild and severe asthma risk.

\begin{tabular}{|c|c|c|c|c|c|c|c|}
\hline Genotypes & $\begin{array}{c}\text { Controls, } \\
(\mathrm{N}=311) \\
\mathrm{n}(\%)\end{array}$ & $\begin{array}{l}\text { Mild asthma } \\
(\mathrm{N}=171) \\
\mathrm{n}(\%)\end{array}$ & $\begin{array}{l}\text { Adjusted } \\
\text { ORs } \\
(95 \% \mathrm{CI})\end{array}$ & $\begin{array}{l}\text { Adjusted } \\
\text { P-values }\end{array}$ & $\begin{array}{l}\text { Severe asthma } \\
\qquad(\mathrm{N}=128) \\
\mathrm{n}(\%)\end{array}$ & $\begin{array}{l}\text { Adjusted } \\
\text { ORs } \\
(95 \% \mathrm{CI})\end{array}$ & $\begin{array}{l}\text { Adjusted } \\
\text { P-values }\end{array}$ \\
\hline \multicolumn{8}{|c|}{ ADAM33 (V4) } \\
\hline GG & $214(68.8)$ & $76(44.4)$ & 1.00 & & $55(43.0)$ & 1.00 & \\
\hline GC & $84(27.0)$ & $79(46.2)$ & $3.00(1.29-6.87)^{\mathrm{a}}$ & $0.011^{\mathrm{a}}$ & $57(44.5)$ & $2.77(1.15-6.66)^{\mathrm{a}}$ & $0.023^{\mathrm{a}}$ \\
\hline $\mathrm{CC}$ & $13(4.2)$ & $16(9.4)$ & $5.99(0.91-39.69)^{\mathrm{a}}$ & $0.063^{\mathrm{a}}$ & $16(12.5)$ & $8.32(3.31-101.29)^{\mathrm{a}}$ & $0.001^{\mathrm{a}}$ \\
\hline $\mathrm{GC} / \mathrm{CC}$ & $97(31.2)$ & $95(55.6)$ & $3.19(1.41-7.21)^{\mathrm{a}}$ & $0.005^{\mathrm{a}}$ & $73(57.0)$ & $3.81(1.67-8.71)^{\mathrm{a}}$ & $0.002^{\mathrm{a}}$ \\
\hline \multicolumn{8}{|c|}{ ADAM33 (T2) } \\
\hline GG & $259(83.3)$ & $115(67.3)$ & 1.00 & & $71(55.4)$ & 1.00 & \\
\hline GA & $48(15.4)$ & $43(25.1)$ & $1.48(0.57-3.81)$ & 0.417 & $49(38.3)$ & $2.17(0.89-5.26)$ & 0.088 \\
\hline $\mathrm{AA}$ & $4(1.3)$ & $13(7.6)$ & $3.94(0.62-25.18)$ & 0.147 & $8(6.3)$ & $3.16(0.40-25.00)$ & 0.275 \\
\hline \multicolumn{8}{|c|}{ ADAM33 (S2) } \\
\hline $\mathrm{CC}$ & $158(50.8)$ & $81(47.4)$ & 1.00 & & $49(38.3)$ & 1.00 & \\
\hline CG & $114(36.7)$ & $76(44.4)$ & $1.96(0.85-4.55)$ & 0.116 & $57(44.5)$ & $0.92(0.42-2.00)$ & 0.827 \\
\hline GG & $39(12.5)$ & $14(8.2)$ & & & $22(17.2)$ & & \\
\hline \multicolumn{8}{|c|}{ ADAM33 (T1) } \\
\hline $\mathrm{AA}$ & $229(73.6)$ & $81(47.4)$ & 1.00 & & $63(49.2)$ & 1.00 & \\
\hline $\mathrm{AG}$ & $71(22.9)$ & $79(46.2)$ & $1.73(0.73-4.10)$ & 0.216 & $44(34.4)$ & $1.43(0.57-3.56)$ & 0.444 \\
\hline GG & $11(3.5)$ & $11(6.4)$ & $0.65(0.70-6.10)$ & 0.706 & $21(16.4)$ & $2.03(0.42-9.80)$ & 0.381 \\
\hline \multicolumn{8}{|c|}{ TGF- $\beta 1$ (T869C) } \\
\hline $\mathrm{TT}$ & $110(35.4)$ & $65(38.0)$ & 1.00 & & $52(40.6)$ & 1.00 & \\
\hline $\mathrm{CT}$ & $147(47.3)$ & $89(52.0)$ & $1.09(0.48-2.48)$ & 0.829 & $54(42.2)$ & $0.56(0.24-1.33)$ & 0.187 \\
\hline $\mathrm{CC}$ & $54(17.3)$ & $17(10.0)$ & $2.18(0.57-8.34)$ & 0.255 & $22(17.2)$ & $2.17(0.62-7.65)$ & 0.227 \\
\hline \multicolumn{8}{|c|}{ TGF- $\beta 1$ (C-509T) } \\
\hline $\mathrm{CC}$ & $136(43.7)$ & $46(26.9)$ & 1.00 & & $33(25.8)$ & 1.00 & \\
\hline $\mathrm{CT}$ & $134(43.1)$ & $92(53.8)$ & $2.73(1.16-6.42)^{\mathrm{a}}$ & $0.022^{\mathrm{a}}$ & $68(53.1)$ & $2.56(1.09-5.99)^{\mathrm{a}}$ & $0.031^{\mathrm{a}}$ \\
\hline TT & $41(13.2)$ & 33 (19.3) & $1.49(0.43-5.09)$ & 0.529 & $27(21.1)$ & $1.27(0.34-4.66)$ & 0.723 \\
\hline $\mathrm{CT} / \mathrm{TT}$ & $175(56.3)$ & $125(73.1)$ & $2.34(1.05-5.24)^{\mathrm{a}}$ & $0.038^{\mathrm{a}}$ & $95(74.2)$ & $2.19(0.98-4.93)^{\mathrm{a}}$ & $0.058^{\mathrm{a}}$ \\
\hline
\end{tabular}

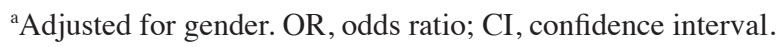

\section{Results}

Social-demographical characteristics. In the present study, 299 cases, including 171 patients suffering from mild asthma and 128 suffering from severe asthma, and 311 controls were recruited. As shown in Table II, no significant difference was detected in terms of gender and age between the control and case groups. The forced expiratory volume in one second (FEV1) of the mild asthma patients $(88.4 \pm 12.11 / \mathrm{sec})$ was higher than that of the severe patients $(67.2 \pm 15.3 \mathrm{l} / \mathrm{sec})$.

Associations of genetic variants with asthma risk. Associations between the genetic variants and asthma risk are shown in Tables III and IV. Table III shows that the SNPs at V4 (rs2787094) of ADAM33 and TGF- 31 C509T (rs1800469) were associated with an increased asthma risk. Compared with the V4 GG genotype carriers, increased susceptibilities to asthma for the GC and CC carriers were detected and the ORs were 2.92 (95\% CI, 1.46-5.85) and 10.56 (95\% CI, 2.17-51.67), respectively. Compared with the rs1800469CC genotype, an increased susceptibility for the CT/TT genotype carriers to asthma was observed and the OR was 2.26 (95\% CI, 1.19-4.30). No significant association was detected between the remaining SNPs and asthma risk.

In Table IV, the SNP at V4 of ADAM33 (rs2787094) was found to be associated with mild and severe asthma risk. Compared with the GG genotype carriers, increased susceptibilities to mild and severe asthma for those carrying the $\mathrm{GC} /$ CC genotype was detected and the ORs were 3.19 (95\% CI, 1.41-7.21) and 3.81 (95\% CI, 1.67-8.71). The SNP at TGF- $\beta 1$ C509T (CT/TT vs. CC) was associated with an increased mild asthma risk (OR, 2.34; 95\% CI, 1.05-5.24) and a marginally significant association between the SNP and severe asthma risk was detected (OR, 2.19; 95\% CI, 0.98-4.93).

Associations between haplotypes and asthma risk. Associations between the ADAM33 haplotypes and asthma risk are shown in Table V. The GGCA haplotype at V4, T2, S2 and T1 of ADAM33 was found to be most frequent and was regarded as a reference. Compared with the GGCA haplo- 
Table V. Associations of ADAM33 haplotypes and asthma risk.

\begin{tabular}{|c|c|c|c|c|c|c|}
\hline V4 & $\mathrm{T} 2$ & $\mathrm{~S} 2$ & $\mathrm{~T} 1$ & $\begin{array}{l}\text { Frequencies } \\
\qquad(\%)\end{array}$ & $\begin{array}{c}\text { ORs } \\
(95 \% \mathrm{CI})^{\mathrm{a}}\end{array}$ & P-value \\
\hline $\mathrm{G}$ & G & $\mathrm{C}$ & A & 35.98 & 1.00 (Reference) & \\
\hline $\mathrm{C}$ & G & $\mathrm{C}$ & A & 8.93 & $1.20(0.41-3.48)$ & 0.737 \\
\hline $\mathrm{C}$ & $\mathrm{G}$ & $\mathrm{C}$ & G & 4.49 & $31.12(4.79-202.31)$ & 0.000 \\
\hline $\mathrm{C}$ & G & G & A & 5.70 & $12.24(3.58-41.92)$ & 0.000 \\
\hline G & A & $\mathrm{C}$ & A & 4.44 & $4.73(1.35-16.50)$ & 0.016 \\
\hline $\mathrm{G}$ & $\mathrm{A}$ & $\mathrm{C}$ & $\mathrm{G}$ & 3.78 & $30.85(4.92-193.55)$ & 0.000 \\
\hline $\mathrm{G}$ & $\mathrm{A}$ & $\mathrm{G}$ & A & 2.77 & $4.83(1.09-21.40)$ & 0.040 \\
\hline G & $\mathrm{G}$ & $\mathrm{C}$ & G & 9.29 & $1.81(0.69-4.73)$ & 0.227 \\
\hline $\mathrm{G}$ & G & G & A & 16.31 & $1.31(0.61-2.81)$ & 0.487 \\
\hline - & - & - & - & $8.31^{\mathrm{b}}$ & $1.95(0.77-4.94)$ & 0.161 \\
\hline
\end{tabular}

${ }^{\mathrm{a}}$ Adjusted for gender; ${ }^{\mathrm{b}}$ Merged frequency of the haplotypes frequencies $<2.5 \%$. OR, odds ratio; CI, confidence interval.

Table VI. Associations of TGF- $\beta 1$ haplotypes with asthma risk.

\begin{tabular}{lcccc}
\hline T869 & 509 & Frequencies & OR $(95 \% \text { CI })^{\mathrm{a}}$ & P-value \\
\hline $\mathrm{T}$ & $\mathrm{T}$ & 0.368 & $1.00($ Reference $)$ & \\
$\mathrm{T}$ & $\mathrm{C}$ & 0.240 & $1.51(0.85-2.65)$ & 0.158 \\
$\mathrm{C}$ & $\mathrm{T}$ & 0.229 & $0.76(0.42-1.38)$ & 0.365 \\
$\mathrm{C}$ & $\mathrm{C}$ & 0.163 & $1.39(0.81-2.38)$ & 0.228 \\
\hline
\end{tabular}

${ }^{\text {a} A d j u s t e d ~ f o r ~ g e n d e r . ~ O R, ~ o d d s ~ r a t i o ; ~ C I, ~ c o n f i d e n c e ~ i n t e r v a l . ~}$

type carriers, an increased risk for those with CGCA, CGCG, CGGA, GACA, GACG and GAGA haplotypes was detected and the ORs were 1.20 (95\% CI, 0.41-3.48), 31.12 (95\% CI, 4.79-202.31), 12.24 (95\% CI, 3.58-41.92), 4.73 (95\% CI, 1.35-16.50), 30.85 (95\% CI, 4.92-193.55) and 4.83 (95\% CI, 1.09-21.40), respectively. However, the associations of the GG, CG and GGGA haplotypes with asthma risk were not significant.

Associations of the TGF- $\beta 1$ haplotype at T869C and T509C are shown in Table VI. The TT haplotype was the most frequent and compared with the haplotype, no significant association of the $\mathrm{TC}, \mathrm{CT}$ or $\mathrm{CC}$ haplotype with asthma risk was detected.

\section{Discussion}

Asthma is a common chronic respiratory disease, with $>155$ million patients suffering from the disease worldwide (25). Bronchial asthma is a complex disease and finding the main factors that are involved in the pathogenesis of asthma is useful, in order to identify the genetic variants that are involved in asthma risk. The validated genetic variants are useful in identification of the individuals that have a high asthma risk and this could provide more information for disease prevention. Therefore, the associations of each single
SNP, and the TGF- $\beta 1$ and ADAM33 haplotypes with asthma risk were evaluated among Chinese children in the present study.

The ADAM33 gene is located on chromosome 20p13, and initially there were 37 SNPs identified (6). The first studies on the associations between ADAM33 polymorphisms and asthma risk were carried out among Caucasian populations in the United Kingdom and the USA. However, the conclusions of the majority of those studies were inconsistent (?). Previous studies reported that the genetic variants in ADAM33 were associated with an increased susceptibility to asthma in Thai (26), Colombia (8) and Indian populations (27). By contrast, no significant association was found between asthma and ADAM33 in Puerto Rican, Mexican (28) and Korean populations (29). The studies may have been affected by sample sizes, heterogeneity of populations and various environmental factors. Subsequent to the cases being divided into mild and severe asthma groups according to disease severity, associations of the SNPs and haplotypes of ADAM 33 and TGF- $\beta 1$ with asthma risk were analyzed in the present study. The SNPs of rs2787094 at ADAM33 V4 and rs1800469 at TGF- $\beta 1 C-509 \mathrm{~T}$ were found to be associated with an increased asthma risk and the ADAM33 haplotypes were useful in predicting the individuals with a high asthma risk.

TGF- $\beta 1$ is a multifunctional cytokine that has the potential to inhibit T-cell activity by regulating cell proliferation, and as a result reduce the asthma onset $(30,31)$. On the other hand, previous studies have indicated that epithelial fibrosis is one of the principle features in airway remodelling in asthma initiation and development, and could be enhanced in a number of patients (32). Numerous studies have revealed that TGF- $\beta 1 \mathrm{C}-509 \mathrm{~T}$ and T869C polymorphisms are associated with an increased TGF- $\beta 1$ production. Burton et al (33) reported that the -509T allele was associated with increased transcriptional activity of TGF- $\beta 1$ compared with the $-509 \mathrm{C}$ allele. In addition, the polymorphism has been confirmed to be associated with asthma risk (34) and severity (35). The T869C polymorphism, which could result in a leucine to proline substitution, was found to be associated with increased TGF- $\beta 1$ mRNA and production level in peripheral blood mononuclear cells (36). In their study, de Faria et al (5) also revealed that the T869C polymorphisms may be involved in the modulation of asthma. In the present study, the $-509 \mathrm{~T}$ allele frequency was observed to be significantly higher in the asthma group compared with the controls, and the CC genotype of C-509T carriers in the asthmatic groups were significantly different from the control group, indicating a possible association of this SNP with asthma. For the SNP T869C, the difference in genotype and allelic frequency was significant between the asthmatic group and controls. The conclusion was consistent with a previous study by Wiśniewski et al (37).

Asthma is a chronic respiratory disease that could be affected by a complex genetic background, and multiple genes have been involved in its development through modified gene expressions and functions. Accumulating evidence (38-41) has indicated that ADAM 33 and TGF- $\beta$ contribute to the biogenesis of asthma, and certain genetic variants in ADAM33 and TGF- $\beta 1$ were found to be responsible for the modified child- 
hood asthma risk in the present study. The ADAM33 haplotypes may be useful and effective biomarkers in predicting asthma risk. However, the sample size of the study is the main limitation and further studies with larger sample sizes are necessary to verify the conclusion of the study.

\section{References}

1. Huang JL: Asthma severity and genetics in Taiwan. J Microbiol Immunol Infect 38: 158-163, 2005.

2. Holgate ST, Davies DE, Lackie PM, Wilson SJ, Puddicombe SM and Lordan JL: Epithelial-mesenchymal interactions in the pathogenesis of asthma. J Allergy Clin Immunol 105: 193-204, 2000

3. Cookson W: The alliance of genes and environment in asthma and allergy. Nature 402 (6760 Suppl): B5-B11, 1999.

4. Ober $\mathrm{C}$ and Thompson EE: Rethinking genetic models of asthma: the role of environmental modifiers. Curr Opin Immunol 17: 670-678, 2005

5. de Faria IC, de Faria EJ, Toro AA, Ribeiro JD and Bertuzzo CS Association of TGF-beta1, CD14, IL-4, IL-4R and ADAM33 gene polymorphisms with asthma severity in children and adolescents. J Pediatr (Rio J) 84: 203-210, 2008.

6. Van Eerdewegh P, Little RD, Dupuis J, et al: Association of the ADAM33 gene with asthma and bronchial hyperresponsiveness. Nature 418: 426-430, 2002

7. Zhang X, Su D, Zhang X, et al: Association of ADAM33 gene polymorphisms with adult concomitant allergic rhinitis and asthma in Chinese Han population. Mol Biol Rep 36: 1505-1509, 2009.

8. Vergara CI, Acevedo N, Jiménez S, et al: A Six-SNP haplotype of ADAM33 is associated with asthma in a population of Cartagena, Colombia. Int Arch Allergy Immunol 152: 32-40, 2010.

9. Awasthi S, Tripathi P, Ganesh S and Husain N: Association of ADAM33 gene polymorphisms with asthma in Indian children. J Hum Genet 56: 188-195, 2010.

10. Raby BA, Silverman EK, Kwiatkowski DJ, Lange C, Lazarus R and Weiss ST: ADAM33 polymorphisms and phenotype associations in childhood asthma. J Allergy Clin Immunol 113 1071-1078, 2004.

11. Schedel M, Depner M, Schoen C, et al: The role of polymorphisms in ADAM33, a disintegrin and metalloprotease 33, in childhood asthma and lung function in two German populations. Respir Res 7: 91, 2006.

12. Noguchi E, Ohtsuki Y, Tokunaga K, et al: ADAM33 polymorphisms are associated with asthma susceptibility in a Japanese population. Clin Exp Allergy 36: 602-608, 2006.

13. Fujii D, Brissenden JE, Derynck R and Francke U: Transforming growth factor beta gene maps to human chromosome 19 long arm and to mouse chromosome 7. Somat Cell Mol Genet 12: 281-288, 1986.

14. Kim SJ, Glick A, Sporn MB and Roberts AB: Characterization of the promoter region of the human transforming growth factor-beta 1 gene. J Biol Chem 264: 402-408, 1989.

15. Nakao A: Is TGF-betal the key to suppression of human asthma? Trends Immunol 22: 115-118, 2001.

16. Lawrence DA: Transforming growth factor-beta: a general review. Eur Cytokine Netw 7: 363-374, 1996.

17. Watanabe Y, Kinoshita A, Yamada T, et al: A catalog of 106 single-nucleotide polymorphisms (SNPs) and 11 other types of variations in genes for transforming growth factor-betal (TGF-beta1) and its signaling pathway. J Hum Genet 47: 478-483, 2002.

18. Nagpal K, Sharma S, B-Rao C, et al: TGFbetal haplotypes and asthma in Indian populations. J Allergy Clin Immunol 115: $527-533,2005$

19. Pulleyn LJ, Newton R, Adcock IM and Barnes PJ: TGFbeta1 allele association with asthma severity. Hum Genet 109: 623-627, 2001.

20. Chiang $\mathrm{CH}$, Lin MW, Chung MY and Yang UC: The association between the IL-4, ADR $\beta 2$ and ADAM 33 gene polymorphisms and asthma in the Taiwanese population. J Chin Med Assoc 75: 635-643, 2012

21. Tripathi P, Awasthi S, Prasad R and Ganesh S: Haplotypic association of ADAM33 (T+1, S+1 and V - 3) gene variants in genetic susceptibility to asthma in Indian population. Ann Hum Biol 39: 479-483, 2012.
22. Majak P, Jurałowicz D, Jerzyńska J, Smejda K, Stelmach W and Stelmach I: Transforming growth factor-beta1 and IL-13 response to allergen predict steroid needs in asthmatic children. Pulm Pharmacol Ther 26: 290-295, 2013.

23. Ierodiakonou D, Postma DS, Koppelman GH, Gerritsen J, ten Hacken NH, Timens W, Boezen HM and Vonk JM: TGF- $\beta 1$ polymorphisms and asthma severity, airway inflammation, and remodeling. J Allergy Clin Immunol 131: 582-585, 2013.

24. Bateman ED, Hurd SS, Barnes PJ, et al: Global strategy for asthma management and prevention: GINA executive summary. Eur Respir J 31: 143-178, 2008.

25. Hoffjan S and Ober C: Present status on the genetic studies of asthma. Curr Opin Immunol 14: 709-717, 2002.

26. Thongngarm T, Jameekornrak A, Limwongse C, et al: Association between ADAM33 polymorphisms and asthma in a Thai population. Asian Pac J Allergy Immunol 26: 205-211, 2008.

27. Tripathi P, Awasthi S, Prasad R, Husain N and Ganesh S: Association of ADAM33 gene polymorphisms with adult-onset asthma and its severity in an Indian adult population. J Genet 90: 265-273, 2011.

28. Lind DL, Choudhry S, Ung N, et al: ADAM33 is not associated with asthma in Puerto Rican or Mexican populations. Am J Respir Crit Care Med 168: 1312-1316, 2003.

29. Lee JH, Park HS, Park SW, et al: ADAM33 polymorphism: association with bronchial hyper-responsiveness in Korean asthmatics. Clin Exp Allergy 34: 860-865, 2004.

30. Li MO, Sanjabi S and Flavell RA: Transforming growth factor-beta controls development, homeostasis, and tolerance of $\mathrm{T}$ cells by regulatory $\mathrm{T}$ cell-dependent and -independent mechanisms. Immunity 25: 455-471, 2006.

31. Wahl SM and Chen W: Transforming growth factor-beta-induced regulatory $\mathrm{T}$ cells referee inflammatory and autoimmune diseases. Arthritis Res Ther 7: 62-68, 2007.

32. Minshall EM, Leung DY, Martin RJ, et al: Eosinophil-associated TGF-beta1 mRNA expression and airways fibrosis in bronchial asthma. Am J Respir Cell Mol Biol 17: 326-333, 1997.

33. Burton T, Liang B, Dibrov A and Amara F: Transforming growth factor-beta-induced transcription of the Alzheimer beta-amyloid precursor protein gene involves interaction between the CTCF-complex and Smads. Biochem Biophys Res Commun 295: 713-723, 2002.

34. Silverman ES, Palmer LJ, Subramaniam V, et al: Transforming growth factor-beta1 promoter polymorphism C-509T is associated with asthma. Am J Respir Crit Care Med 169: 214-219, 2004.

35. Li H, Romieu I, Wu H, et al: Genetic polymorphisms in transforming growth factor beta-1 (TGFB1) and childhood asthma and atopy. Hum Genet 121: 529-538, 2007.

36. Dunning AM, Ellis PD, McBride S, et al: A transforming growth factorbeta 1 signal peptide variant increases secretion in vitro and is associated with increased incidence of invasive breast cancer. Cancer Res 63: 2610-2615, 2003.

37. Wiśniewski A, Obojski A, Pawlik A, et al: Polymorphism of the TGFB1 gene is not associated with bronchial allergic asthma in a Polish population. Hum Immunol 70: 134-138, 2009

38. Tripathi P, Awasthi S, Husain N, Prasad R and Mishra V: Increased expression of ADAM33 protein in asthmatic patients as compared to non-asthmatic controls. Indian J Med Res 137: 507-514, 2013.

39. Al-khayyat Al, Al-Anazi M, Warsy A, Vazquez-Tello A, Alamri AM, Halwani R, Alangari A, Al-Frayh A, Hamid Q and Al-Muhsen S: T1 and T2 ADAM33 single nucleotide polymorphisms and the risk of childhood asthma in a Saudi Arabian population: a pilot study. Ann Saudi Med 32: 479-486, 2012.

40. Eusebio M, Kraszula L, Kupczyk M, Kuna P and Pietruczuk M: The effects of interleukin-10 or TGF-beta on anti-CD3/CD28 induced activation of $\mathrm{CD} 8^{+} \mathrm{CD} 28^{-}$and $\mathrm{CD} 8^{+} \mathrm{CD} 28^{+} \mathrm{T}$ cells in allergic asthma. J Biol Regul Homeost Agents 27: 681-692, 2013.

41. Jiang K, Chen HB, Wang Y, Lin JH, Hu Y and Fang YR: Changes in IL-17 and TGF- $\beta 1$ levels in serum and bronchoalveolar lavage fluid and their clinical significance among children with asthma. Zhongguo Dang Dai Er Ke Za Zhi 15: 604-608, 2013 (In Chinese). 